Meta

Journal des traducteurs

Translators' Journal

\title{
Translation in Medieval and Reformation Norway: A History of Stories or the Story of History
}

\section{Elizabeth Rasmussen}

Volume 49, numéro 3, septembre 2004

L'histoire de la traduction et la traduction de l'histoire History of Translation and Translation of History

URI : https://id.erudit.org/iderudit/009382ar

DOI : https://doi.org/10.7202/009382ar

Aller au sommaire du numéro

Éditeur(s)

Les Presses de l'Université de Montréal

ISSN

0026-0452 (imprimé)

1492-1421 (numérique)

Découvrir la revue

Citer cet article

Rasmussen, E. (2004). Translation in Medieval and Reformation Norway: A History of Stories or the Story of History. Meta, 49(3), 629-645.

https://doi.org/10.7202/009382ar

\section{Résumé de l'article}

La production, le style, et les conventions littéraires de la Norvège médiévale ont été formés par trois événements majeurs : l’introduction du christianisme, la Peste noire, et la Réforme. Les textes importés ont été essentiels à la transition entre le temps des Vikings et le Moyen Âge chrétien ainsi qu'au passage vers la fois protestante du XVI $\mathrm{I}^{\mathrm{e}}$ siècle. L'absence de production littéraire et de traduction à la suite de la Peste noire a aussi eu un effet non négligeable.

Le terme traduction comprend, dans un contexte médiéval, le transfert des connaissances et le passage des frontières linguistiques et culturelles. Les textes importés ont facilité l'introduction, la dissémination, et le maintien de la foi chrétienne. La distinction entre conte et histoire s'est en quelque sorte effacée. Le matériel religieux et didactique a précédé les textes séculaires en provenance des cours des territoires francophones. Les hagiographies ont vécu en parallèle avec les récits chevaleresques et héroïques. Tous les genres ont illustré les vertus de la foi et de la société chrétienne et n'ont eu besoin que de modifications mineures pour plaire à l'audience norvégienne. Les conventions littéraires traditionnelles ont rejoint les conventions importées pour engendrer un style courtois norrois typique.

Le rencontre systématique avec l'autre a rendu la perception de soi plus aiguë. Les traducteurs, restés pour la plupart anonymes, ont largement contribué à l'assimilation des valeurs nouvelles venant de l'étranger.
Ce document est protégé par la loi sur le droit d'auteur. L’utilisation des services d’Érudit (y compris la reproduction) est assujettie à sa politique d'utilisation que vous pouvez consulter en ligne.

https://apropos.erudit.org/fr/usagers/politique-dutilisation/ 


\title{
Translation in Medieval and Reformation Norway: A History of Stories or the Story of History
}

\author{
ELIZABETH RASMUSSEN \\ Traductrice indépendante \\ verbatio@videotron.ca
}

\section{RÉSUMÉ}

La production, le style, et les conventions littéraires de la Norvège médiévale ont été formés par trois événements majeurs: l'introduction du christianisme, la Peste noire, et la Réforme. Les textes importés ont été essentiels à la transition entre le temps des Vikings et le Moyen Âge chrétien ainsi qu'au passage vers la fois protestante du $\mathrm{XVI}^{\mathrm{e}}$ siècle. L'absence de production littéraire et de traduction à la suite de la Peste noire a aussi eu un effet non négligeable.

Le terme traduction comprend, dans un contexte médiéval, le transfert des connaissances et le passage des frontières linguistiques et culturelles. Les textes importés ont facilité l'introduction, la dissémination, et le maintien de la foi chrétienne. La distinction entre conte et histoire s'est en quelque sorte effacée. Le matériel religieux et didactique a précédé les textes séculaires en provenance des cours des territoires francophones. Les hagiographies ont vécu en parallèle avec les récits chevaleresques et héroïques. Tous les genres ont illustré les vertus de la foi et de la société chrétienne et n'ont eu besoin que de modifications mineures pour plaire à l'audience norvégienne. Les conventions littéraires traditionnelles ont rejoint les conventions importées pour engendrer un style courtois norrois typique.

Le rencontre systématique avec l'autre a rendu la perception de soi plus aiguë. Les traducteurs, restés pour la plupart anonymes, ont largement contribué à l'assimilation des valeurs nouvelles venant de l'étranger.

\section{ABSTRACT}

Three major events marked medieval Norwegian literary production, style, and language: the introduction of Christianity, the Black Death, and the Reformation. Foreign material in translation was pivotal to the transition between the pagan Viking Era and the Christian Middle Ages and to the passage from Catholicism to Lutheranism in the 16th century. Lack of translation and literary production following the Black Death also had an impact.

Translation in a medieval and Renaissance context must be understood as transfer of knowledge, the crossing of linguistic and cultural borders. The translated texts helped introduce and consolidate the social conventions promoted by the new religion. The distinction between story and history faded. Religious and devotional material preceded the secular court literature from the French-speaking territories. Hagiographic material ran parallel to heroic tales: all genres helped illustrate the virtues of Christian life and social organization and needed only minor adaptation for a Norse audience. The pagan literary conventions blended with those of the imported material and resulted in a distinct Norse literary style.

The systematic encounter with other gave rise to a new perception of self. The largely anonymous translators contributed to the inclusion of other in self, to the assimilation of foreign cultural values and concepts.

\section{MOTS-CLÉS/KEYWORDS}

Middle Ages, reformation, 16th century, literary translation, Norway 


\section{Introduction}

The Old Norse culture changed radically as a result of the encounter with the ideas and conventions conveyed by the Christian texts in the Middle Ages. Their selection was not random, but served a rather ambitious didactical scheme undertaken primarily by members of the Church, who saw a need for exemplification and instruction in appropriate Christian behavior. Translation in medieval Norway was not only a matter of knowledge transfer; it signified cultural colonialization and assimilation, it was an indispensable tool in the effort to reshape the native mentality.

In medieval Christian Norway, the vernacular remained the language of communication and civil administration. The old and new laws were recorded in the Old Norse language as a matter of course. The ancestral laws were not suppressed by the new Christian principles, the latter were incorporated into the existing codex. To all probability, the Norse tongue was taught alongside Latin in the Christian schools that were established. Translators into Old Norse never apologized for using the vernacular as did so profusely their European colleagues. Rather, prefaces to Old Norse translations introduced and explained what was about to be read, and were often accompanied by an enumeration of the benefits that the text would bestow upon the reader. The vernacular remained the lingua franca in most social and administrative contexts. All of this was rather unique from a European contemporaneous perspective.

A comprehensive history and analysis of the imported texts and their combined influence on the Old Norse mentality and social organization has yet to be written. The old texts have been studied separately by a number of scholars from various disciplines such as theology, philology and linguistics. Translation as an agent of change has been neglected by both historians and linguists. In my recent thesis (Concordia University, September 2002), I have however made an attempt at establishing a "repertoire" of translations undertaken in Norway from which detailed analyses can be made possible, showing both the scope and extent of the enterprise. Far from being a simple matter of importing foreign stories, translation in medieval Norway was an enterprise rooted in a sincere wish to introduce, promote and indoctrinate the basic notions of Christianism: yet we see an all too clear will to manipulate and control, reflecting the ongoing struggle between the Church and a succession of kings. History is not a simple succession of events. It is a maze of interlocking and multilayered factual and discursive events, of actions and reactions. The history of translation conveys a distinct perception of the past. The translators and their texts shaped history. Discursive and factual events had a reciprocal effect on each other that we cannot continue to ignore.

\section{The Coming of Christianity: Reshaping the Mentality}

Three major events marked Norwegian literary production throughout the Middle Ages: the introduction of Christianity, the Black Death, and the Reformation. They all meant a radical change of direction, they all implied major social and mental reorganization.

Long before the introduction of Christianity, the people of the North had been in regular contact with foreign cultures. The Norse people had been great travelers and merchants from before the Viking Age. Notwithstanding their somewhat dubious 
reputation as warriors and robbers, the Norsemen had developed commercial ties with a number of nations and regions, and had interacted with Christian communities for centuries before Christianity was introduced.

In the Old Norse society, religion was associated with the inherited wisdom and experience of the forefathers. The clan and its families were at the center of social as well as religious organization. The gods were the clan's closest companions and friends, physically present at the farm, in tools and weapons, in a spring, a tree, a mound, or in an entire mountain. Religion focused on life as it unfolded on earth. The purpose of religious devotion was to maintain human life. People therefore needed the immediate support of the gods. And the gods were place-bound. Foreign religions were not a concern for the Norsemen, who accepted the fact that different places needed the protection of different gods. Christianity was not unknown to the people of the North, rather it was out of place, belonging elsewhere. The Norse religion was in many ways a tolerant one. Based on tradition, not on a written codex, it was practiced collectively. The seasonal rites created bonds between people, within the clan and across clan-lines. Conversion to Christianity by just one family member was considered an act of disloyalty, not only to the gods but to the ancestors and the entire clan. To break the bonds of community and convert without the consent of the clan was considered an outrage and a shame (frendeskam). This explains why so many were unwilling to accept Christianity in the early days, and why some families and clans converted as a group. In Iceland, for instance, Christianity was adopted by a regular vote at the Althing like any other communal decision.

This collective form of devotion stands in sharp contrast to the increasingly individualized Christian religion. Common sense and experience stood against philosophy and reflection. There was a world of difference between the Old Norse emphasis on honor, personal courage, skillfulness, performance and pride and the Christian ideals of submission, humbleness, and penitence in preparation for life after death. A number of adjustments were warranted.

The material translated in medieval Norway helped the Church achieve a much needed religious and social conformity with the rest of Christianity. Translation, as practiced in Norway, meant knowledge transfer on an unprecedented scale, including adaptation, paraphrase, imitation, re-writing, summary, and compilation. The imported texts opened up for an encounter between self and other in a unique way, and allowed for the appropriation and adaptation of a foreign culture and its literary expression. As manuscripts and ideas flowed in, the focus of Norwegian leaders turned outwards, away from the local towards the foreign.

\section{Iceland and Norway: Separate Entities?}

There was a constant movement of scholars and manuscripts between Iceland and Norway. Texts were translated, written, compiled, and disseminated in the two communities almost simultaneously. The ecclesiastic administrations of the two communities were officially coordinated in the 12th century, when the Archdiocese in Nidaros gained ecclesiastical control over the Arctic regions and the Atlantic Islands. The close ties between Norway and Iceland has made the question of textual origin all the more complicated, and continues to preoccupy scholars. The Icelanders were indeed champions of the historical genre. It is, however, generally conceded that the 
translation of most of the didactical material and court literature was a mainly Norwegian enterprise.

\section{Religious Texts}

The religious material preceded the secular texts. Soon, however, almost every genre was imported: religious and devotional texts; legends; heroic tales; and chivalric and romance material. The early missionaries depended on vernacular manuals to explain the main articles of the faith, to be able to celebrate Holy Mass, and to combat pagan rites and beliefs. The first clergy from the British Isles may have used homilies and liturgical material in Old English as this language was relatively close to Old Norse.

A fairly considerable body of religious literature in the vernacular existed in both Iceland and in Norway by the middle of the 12th century. The texts in Humiliúbók for instance may possibly have existed as a fixed collection from the end of the 11th century on. However, the majority of translations - regardless of genre were undertaken during the rule of Håkon Håkonsson in the 13th century. The Old Norse version of Vitae Patrum, for example, survived as part of a large Icelandic codex known as Stcerri Stjórn, along with Romverja saga, Alexanders saga, and Gy ing a saga. This collection apparently functioned as a comprehensive world history.

The historical texts of Scripture seem to have captured the Norsemen's imagination early on. Nevertheless, an attempt at a comprehensive translation of the historical material of the Old Testament was not initiated until the beginning of the 14th century, when Stjórn - one of the last Norwegian translations - was produced at the request of Håkon Magnusson. Vulgata was its main source, but Stjórn also contains material from Comestor's Historia scholastica and Beauvais' Speculum historiale, as well as proverbial material from various authoritative sources (i.e., Disticha Catonis). Proverbs were ideal because of their short and concise form and found their equivalence in old native proverbial literature, such as for instance Hávamál.

The Old Norse translators of religious and devotional material carefully edited their work, rearranging and adapting the selected texts according to the needs of the native audience. Many texts were augmented with quotations, commentaries, and personal reflections, and almost all included general advice in matters pertaining to good Christian conduct.

\section{Court Literature from the French Territories}

By 1220, Norway experienced a period of relative peace and prosperity after years of civil war. The elite now had time for recreation and entertainment and wanted to emulate European courtiers. New models for appropriate political and social behavior were needed. These models were found in the court literature from the Frenchspeaking territories, in stories narrating the exploits of legendary heroes in chivalric tales of Arthurian, Carolingian, and Breton origin.

The French court literature derived from mainly three traditions: the matière de Bretagne (represented by the works of Chrétien de Troyes and Marie de France), the matière de France (adventure novels such as Flores oc Blantzeflor and Elis saga ok Rósamunde), and the matière de Rome (Alexanders saga, Romverja, and Trojumanna saga). Medieval tales of other origins, such as Tristan and Isolde (translated into Old 
Norse in 1226) and various legends associated with Charlemagne (especially the Chanson de Roland) were recorded in Old Norse before or around 1250.

\section{Chronicles and Historical Texts}

The matière de Rome, of mainly Latin provenance, was persistently presented as chivalric romance, even though it included a number of foreign Latin chronicles on various topics, such as Einhard's Karlamagnús saga and Monmouth's Breta sögur. The very first Vita Caroli Magni had been written not long after Charlemagne's death in Spain in 840. This text soon gave birth to a tradition of chansons de geste, which in the beginning shared some of the same features as the Breton lais: they were musical poems belonging to the repertory of the countless jesters and troubadours who performed along the many pilgrim routes. The genres intermixed: the gesta with the historia: the legenda with the chronica. Both heroic epic and chivalric romance literature enjoyed great popularity in Norway, as it combined physical action and chivalry with good Christian values.

\section{How Was the Material Presented and How Was It Received?}

How was the foreign material presented and how was it received? The incentive behind the translation of historical, legendary, and heroic court literature cannot have been merely entertainment as some of the prefaces so ardently claim, especially that of Strengleikar. Entertainment was but one aspect. Almost all the texts contain didactical digressions and interlinear commentary. The Lai of Equitan is a good example. This basically funny slapstick-humor story had no didactical intention in its original French form. The Norse translator, however, expanded the epilogue lavishly with his own material, referring to biblical figures (Abraham, Job and Lazarus), quoting Saint Augustine, and introducing proverbial sayings in Latin.

The translated material captured the imagination of the Norwegian audience. What is peculiar is the insistence upon giving these texts of very different linguistic and geographical origin the status of sögur (even riddarasögur) regardless of their textual provenance or style. The translators consciously or unconsciously combined the different imported texts with existing literary conventions, creating a specific Old Norse courteous (kurteiz) style. The foreign was made familiar through compliance with and adaptation of the traditional.

\section{Histories and Stories}

When considering the relationship between history and story, between history and legend, between legend and exemplum, we must not forget the essentially oral aspect of medieval literature. Knowledge dissemination in medieval Norway reflected contemporaneous reading habits. Texts were written for oral performance. A medieval reader would read aloud, even when he (or she) was alone. Legenda literally means "to be read" - implicitly "to be read aloud."

In Norway, the orally performed story signified the continuation of existing literary conventions. The old form helped introduce the new content. Foreign hagiographic material, Christian chivalric and heroic ideals mixed with the traditions of the 
former pagan society. Action was preferred to psychology. By conforming to existing literary conventions, the unfamiliar story of other became the plausible story of self: and the foreign was domesticated.

To a medieval readership and audience, any story could convey fundamental universal truth. Some of the imported stories may have been used by the clergy as exempla, thereby crossing the border between fact and fiction. The secular court literature in Old Norse translation must therefore be considered a supplement to the devotional material that preceded it, as it, too, aimed at instilling in the native population new role models and at consolidating religious beliefs. Indeed, the voice of the translators, heard in the interlinear commentaries, reveals to what extent translators looked upon themselves as social and religious educators.

Looking at the history of translation in medieval Norway, the impression is that of a nation of neophytes struggling to keep up with European intellectual currents and relentlessly working to fully introduce, nourish and maintain the faith. However, this is only a half-truth. The texts also served a political agenda, namely the defense and institution of the Christian king. The translation of Honorius of Autun's Elucidarium - composed in response to the embarrassing controversy over lay investiture in the 11th and 12th centuries - and Hugh of Saint Victor's Soliloquium de arrha animae, in conjunction with the compilation of Konungs skuggsjá, must be understood as the native clergy's need for teaching material in matters pertaining to theology in general and power sharing between Crown and Church in particular. A Christian King was subordinate to Christ, i.e., the Church and its institutions. According to the Church, kings owed allegiance to God first and men next. This was quite contrary to the Old Norse tradition in which religion and politics had been considered distinct but separate aspects of social life and where kings had been chosen amongst peers.

\section{The Black Death: The Disintegration of Social and Political Structures}

Due to a series of political, demographic, and climatic circumstances in the 14th century, literary activity all but ceased in Norway; however, some of the court literature entered the popular tradition and lived on in the form of ballads and folksongs. The remnants of sögur in some cases became adventure stories - or eventyr, taking on native dress and starting a new life independent of scholarly learning.

The devastation of the Black Plague weakened an already fragile political system and opened up for an increased presence of Danish administrators. The Norwegian court moved to Sweden in 1319 when Magnus VII Eriksson, still a child, was acclaimed King of both countries. This union was the first in a series of partnerships and agreements that would weaken the authority of the Norwegian National Council.

The Old Norse language, which had become standardized in the 12th century, continued to be used by the administration until the end of the 14th century when Danish was adopted. The Kalmar Treaty of 1397 marked the de facto beginning of the end of national sovereignty.

In the centuries following the Black Death, the Church was unable to provide adequate schooling for lack of people and revenues. Consequently, the prescriptive and normative influence of schools in matters of grammar and orthography was 
significantly diminished, causing a rapid mutation of the national tongue. By the 16 th century, the Norwegian vernacular had roughly developed into the modern dialects we know today. The old language had been forgotten.

\section{The Resurrection of National Pride: The Humanists of the Reformation Century}

Both the Reformation and the inclusion of the country into the Danish kingdom were imposed upon the people and its leaders. The National Council was dissolved in 1536, and Norway was formally annexed to the kingdom of Denmark. Yet again, Norwegian mentality had to be remolded. Once more, the course must change. For a second time, translation played a part in the process, both in Denmark and in Norway. There was however a significant difference in intellectual focus. In Denmark, Lutheran pamphlets were imported, translated, and debated on a large scale. In Norway, the old sagas came to the fore.

Denmark became Norway's main link to European humanism. There was direct contact between Danish intellectuals and leading humanists (i.e., Erasmus, José Badé, and Thomas More), and through personal friendships with Danish colleagues (Christiern Pedersen and Peder Palladius in particular) the reformed clergy in Bergen were indirectly connected to European humanism.

The Reformation demanded radical changes of both Norwegian society and mentality, and many essential issues had to be addressed. The dioceses were all in dire straits. Revenues were insufficient because the Crown had confiscated most of the church's properties, reducing tithes and taxes. In Bergen, the abusive presence of the Hanseatic merchants, who controlled trade and commerce along the coast, was a sore point. It was widely believed that the Germans were responsible for the general moral decay. The city administrators therefore looked for ways to increase revenues, strengthen religious and moral education, and limit the humiliating privileges of the Hanseatics. In a context of growing frustration with the status quo, a handful of people started reexamining the past in search of solutions to the most urgent problems.

The ancient laws were translated and examined by legal experts - the only people able to read and interpret the Old Norse texts. Their study led to a heightened awareness of the sovereign past and the inherited rights and privileges of both church and people. The recovery of the past fostered an interest in the nation's history and a yearning for a new national identity. Absalon Beyer read the material that was translated at the Chapter and used it as source material for Om Norgis Rige, his very touching personal comments on contemporary political and economical issues.

Beyer was indeed the first author of a Norwegian history since the saga writers, and Bergen may have emerged as a new cultural center had the civil and church administrations not been moved to Oslo in order to be closer to the King's administration in Copenhagen. The intellectual circle in Oslo had both more people and money, and was resolutely more productive than the one in Bergen. This is where the governor resided, and where the reformed humanism grew to maturity in all its Latin apparel. The expression was mainly Latin, but the focus was purely national. Jens Nilssøn wrote Historia regum Norvegiae based on his private Old Norse manuscript collection. Halvard Gunnarssøn translated the kings' sagas into Latin verse (Chronicon regum Norwegiae). 
Towards the end of the century, when Lutheran doctrine had been effectively implemented and the counter-reformation had failed, the time was ripe for new input from abroad. Danish-born Hans Mogensen, Bishop of Trondheim, translated Philippe de Commynes' Mémoires, his personal recollection of Louis XI and Charles VIII. This account was the only foreign vernacular history translated into Danish in the Reformation century. Mogensen's successor, Anders Christensen Aarebo, turned to contemporary reformed French literature, translating the epic La sepmaine by Guillaume du Bartas. In his days, Bartas was considered as great as Ronsard. This translation marked the beginning of a new era for literature in the vernacular in Norway. It was the first timid return to French literature before Ludvig Holberg started composing satirical comedies in the spirit of Molière.

\section{Conclusion}

Translators in medieval Norway had needed imagination and inventiveness. New words had to be created and explained. However, the encounter with the foreign did not suppress the national; rather, it influenced and guided its evolution. The largely anonymous Old Norse translators sought and contributed to the inclusion of other in self, to the assimilation of new cultural values and concepts. The attitude had been extraverted and inclusive, dynamic and open.

European humanism had been a predominantly Latin enterprise, rooted in a long-felt need to re-establish the authoritative texts of Christianity which had been corrupted by generations of commentaries, glossing and compilation. The concern was for auctoritas, the quest was still universal truth. 16th-century Norwegian humanism was an introverted and exclusive activity, almost narcissic in nature, as scholars concentrated on the former self in an attempt to reestablish a sense of pride and nationhood and find workable solutions to fundamental societal problems. Almost the entire Reformation century was dedicated to exploring the nation's not so distant, yet glorious and sovereign past. The movement that had started out as a vernacular phenomenon, ended as a Latin exercise at a time when the vernacular gained ground in other countries. The national identity was strengthened in this retrospective process. In Norway, the Renaissance term of ad fontes had found its own national expression.

\section{APPENDIX 1}

Short Survey of Latin and French Court and Romance Literature in Old Norse Translation

A) Translations of various Latin source texts, including Matière de Rome:

Alexanders saga - About Alexander the Great. Translated after the death of Håkon from a Latin text by Gautier de Chatillon (12th), the style is "Latinized." Translated under Magnus the Law Mender (1263-1280). The text was included in the Norse version of Vitae Patrum (Halvorsen 1959, Tveitane 1968, Togeby 1975).

Amícus saga ok Amilíus. Translated from a Latin text after the reign of Håkon (Togeby 1975).

Breta sögur - A translation of Monmouth's Historia regum britanniae (Venås 1962, Gravier 1972, Barnes 1987).

Clarú saga - Translated into Old Norse by the Icelandic bishop Jon Halldorsson (d.1339) in Bergen around 1300 (Venås 1962, Kalinke 1985, Tveitane 1968). 
Pamphilius ok Galathea - 2nd half of the 13th century. A translation of the Latin Pamphilius de amore, narrating the seduction of Galathea by Pamphilius. The story is written as a dialogue and was included in the Norse manuscript containing Strengleikar along with Elis saga. Marks a return to Latin sources after almost 30 years of translating French texts (Togeby 1975, Cook \& Tveitane 1979).

Samsons saga fagra (The Story of "Fair" Samson).

Trójumanna saga (The History of Troy). Translated from a Latin manuscript (Togeby 1975).

B) Arthurian material:

Erex Saga (Erec et Eneide). Written by Chrétien de Troyes around 1170. One of four romances by Chrétien that were translated into Old Norse. The emphasis is on the mirror aspects of Chrétien's poem, and the translation conveys a concern with regal and chivalric propriety. In Old Norse it became almost a prince's mirror. A rather voluminous poem (Zinc 1975, Barnes 1987, Kalinke 1981 \& 1991).

Geitarlauf (Chèvrefeuille). Part of Strengleikar. One of the only two lais that are, strictly speaking, of Arthurian origin, the other being Januals saga (Lanval) (Kalinke 1981).

Ivens saga (Yvain, ou le chevalier au lion). The original French text was composed by Chrétien de Troyes between 1170 and 1180 and translated into Old Norse at the request of Håkon Håkonson sometime around 1250-57 (Halvorsen 1959, Togeby 1975, Zinc 1975, Cook \& Tveitane 1979).

Janual (Lanval). Part of Strengleikar. Quite a risqué tale about a queen who attempts to seduce one of Arthur's knights (Kalinke 1981).

Möttuls saga (Le mantel mautaillé). The tale of the disconcerting consequences of a chastity test at the not so "courteous" court of King Arthur. This anonymous story, by some attributed to Marie de France, belongs in part to the tradition commonly referred to as the matière de Bretagne. The text was translated for amusement and laughter and was the only Old French fabliau to be translated into Old Norse (Halvorsen 1959, Zinc 1975, Kalinke 1981 \&1991).

Parcevals saga. Translated from Chrétien de Troyes' romance.

Tristrams saga ok Isönder - Translated by Brother Robert in 1226 (Kalinke 1985a, MarchelloNizia1995).

Valvens_attr (The Story of Gawain). This saga derives from Chrétien de Troyes' romance, and was probably translated during the reign of Håkon Håkonsson ( fattr means part of book").

\section{C) Matière de Bretagne:}

Möttuls saga (Le mantel mautaillé). A fabliau of Breton origin. See above.

Strengleikar (The Lais usually attributed to Marie de France) composed sometime between 1160 and 1170 (Laurion 1997). The sequence of the Old Norse lais differs somewhat from that of Marie's collection in the Harley manuscript. Strengleikar contains 21 stories with a Prologue:

Forre a (Prologue). The translator's intention to use the collection of lais as a mirror is quite explicit (Barnes 1987).

Guiamar. In 1979, a new manuscript of the Guiamars saga came to light, older than the manuscript preserved in the De La Gardie collection (Uppsala). This new text reveals a more faithful translation of the original French lai and helps clarify hitherto problematic passages in the extant Norwegian text (Kalinke 1991).

Eskia (Fresne). The text has survived in two French manuscripts.

Equitan. This lai has an explicit exemplary function. The rather lengthy epilogue condemns the vices of cupidity and injustice. Latin quotes and reference to biblical stories echo the style of the King's Mirror, promoting the virtues of fidelity and humility (Barnes 1987). This Lai presents many features of the fabliau (Cook \& Tveitane 1979).

Bisclaret. The story known as Tiodels saga is believed to be a variation on the same theme (Kalinke 1991). The word "Bisclaret" is a loanword, one of the few Celtic words in Strengleikar, and means "werewolf" (Cook \& Tveitane 1979). 
Laüstik. "Laüstic" is a Celtic loanword meaning "nightingale."

Desire

Tiodel. An Icelandic adaptation of Bisclaret (Kalinke 1991).

Chevotel (Chaitivel).

Doun (Doon). Preserved in French only in the Paris manuscript (Cook \& Tveitane 1979).

Tveggia elskande lio (Deus amanz).

Gurun

Milun (Melion).

Geitarlauf (Chèvrefeuille). One of the only two lais that are, strictly speaking, of the Arthurian tradition, the other being the Januals saga (Kalinke 1981). See above.

Strandar strengleikar*

Leikara lio (Le lai du Lecheor). Old French sources tell of Norwegian jongleurs (leikarar) who performed lais to musical accompaniment. The French manuscript of Marie's lais depicts on the first page a jongleur with a vielle - or a "fele $=$ violin" called gigja in Old Norse - playing before a king (Cook \& Tveitane 1979). The Old French word jugleur is translated Leikarar, showing that the jongleur or jester was a known figure in the North. Saint Pantelion was the jongleurs' patron saint (Venås1962, Cook \& Tveitane 1979).

Janual (Lanval). Quite a risqué tale about a queen who attempts to seduce one of Arthur's knights (Kalinke 1981).

Jonet (Yonec).

Naboreis

Ricar hinn gamli ${ }^{\star}$ King Richard the Old = Richard II)

Tveggia elskande strengleikar*

Grelent (Graelent).

D) The Cycle of Charlemagne and Chansons de Geste

Karlamagnús saga. Translated around 1250. In this Old Norse saga the Chanson de Roland and Le pélérinage de Charlemagne were combined in one story. The story of Charlemagne was translated in several stages. The first stages are prior to Håkon Håkonsson, i.e., early in the 13th century. There are several parallels between the earliest Norse Charlemagne tradition and the first Konungesögur. The book contains 10 chansons de geste, of which the Chanson de Roland became the more popular (Venås 1962, Togeby 1975, Lönnroth 1975, Kalinke 1981).

Runzivals_attr-Translated just before 1100, this saga is the earliest Old Norse Chanson de geste. A prose translation of the verse original, it recounts the most famous story of the adventures of Charlemagne (Halvorsen 1959, Lönnroth 1975).

Elis saga ok Rósamunde (The story of Elie de Saint-Gille). Chanson de geste of non-Arthurian origin. A good example of the true Old Norse "court style" (Halvorsen 1959). The preserved manuscript dates from c.1270. Translated from Old French (Togeby 1975, Cook \& Tveitane 1979, Kalinke $1981 \& 1991)$.

Flóvent saga - Translated around 1250 - Chanson de Geste from the Anglo-Norman English court literature (Togeby 1975).

E) Others:

Bevis saga - Beuve de Hantone. A later style (Togeby 1975).

Dínus saga drambláta (Dinus the overly confident).

_i r eks saga. Translated c.1259. A compilation of the legendary tales about Dietrich von Bern. One of the few inputs from German literature (Togeby 1975, Kalinke 1981).

Flóres saga ok Blankiflúr (Flores et Blanchefleur). Of the later romances, from a Mediterranean tradition, and not of Celtic origin. This romance became extremely popular. The Old Norse text dates from the end of the 13th century or the beginning of the 14th century. Its popularity persisted throughout Europe, and Gottfried of Ghemen published it in 1509. One of the two last Old French texts (the other is Partalopa) to be translated at the Norwegian court in Bergen (Bruun 1877, Halvorsen 1959, Togeby 1975, Kalinke 1981, Barnes 1987). 
Jóns saga leikara (John the jongleur's saga).

Olif ok Landres. Translated after Håkon (d. 1263) from an Anglo-Norman text (Togeby 1975).

Partalopa saga - Translated c.1250 (Togeby 1975).

Valdimars saga - Epic poem about the Danish King Valdemar Sejer (1131-1182).

Information extracted from:

Barnes 1987, Bruun 1877, Cook \& Tveitane 1979, Halvorsen 1959, Kalinke 1981, 1985a \& 1985b, 1991, Laurion 1997, Lönnroth 1975, Marchello-Nizia 1995, Togeby 1975, Tveitane 1968, Venås 1962, Zinc 1975, and Koldsrud 1913.

\section{APPENDIX 2}

\section{Short Survey of Biblical, Religious and Devotional Texts in Old Norse Translation}

The selection presented is not exhaustive, but includes the main texts in Old Norse translation, and aims at illustrating the scope of translation of religious and devotional texts in medieval Norway.

Barlaams saga ok Josaphats (first half of 13th century). Preserved in Manuscript No. 6 Fol. in the Royal Library, Stockholm (Rindal 1980, Halvorsen 1959, Astås 1990a).

Book of Psalms. Quotations in Old Norse from the Book of Psalms are found in the Vienna Psalter, Cod. Viund. 2713, AM 241a fol. (Uecker 1980).

Elucidarius (c.1200). This text has survived in four more or less complete manuscripts: AM 674a $4^{\circ}$ is the oldest; AM $6754^{\circ}$, originally part of Hauksbók (AM 675, 4\%) by Haukr Erlendsson (d.1334); AM 544; and AM 238 fol. xviII. Honorius' work was popular medieval reading along with the Vincent of Beauvais Speculum maior (Firchow 1992).

Gy ing a saga (c.1257-63) by Brandr Jónsson (c.1200-1263). Preserved in five more or less complete manuscripts: AM 226 fol., the more complete manuscript from the middle of the 14th century; AM 225 fol.; AM 655, 4, xxv; AM 238 fol. xviI, and AM 229 fol. IV (Wolf 1995). The original titles used were Historia Judaica in AM 435a, 4', and Historia Macchabeorum in AM $654,4^{\circ}$. As these titles outline, the Old Norse story of the Jews was based on the Books of Machabees (Kirby 1986, Wolf 1995).

Heilagra manna sögur (c. 1250-1300) based on Vitae patrum: AM 225 fol. (Unger 1877, Tveitane 1968).

Humiliúbók (c.1200) AM 619, 4º. This manuscript is a copy of an earlier collection (maybe even a copy of a copy), and some of the mistakes and omissions are the result of the copyists' oversight or misunderstandings. It is interesting to note that the translator has kept the original Latin titles for most of the entries, and that only two chapters have Old Norse titles (27 og 31) (See Indrebø 1931, Seip 1952b, Salvesen 1971).

Cve i u-sending Alcuni diaconi (Greetings from Alcuin (735-804)

De nativitate domini sermo (Sermon on the Birth of the Lord)

Sermo ad populum (Sermon for the people)

In nativitate domini nostri Jesu Christi sermo. Omelia Gregorij (Sermon on the Birth of our Lord Jesus Christ)

Sermo de sancto Stephano martire (Sermon on Saint Stephen, the first martyr)

Sermo de euuangelistis. In die sanct Johannis (Sermon on the evangelists. On Saint John the Baptist's Day)

- In die sanctorum innocentium secundum Matheum. Omilia (On the Innocent Children's Day According to Matthew) (28th december)

- In circumcisione domini nostri Jesu Christi sermo (Sermon on the Circumcision of our Lord Jesus Christ)

In epiphania domini sermo necessaria (Indispensable Sermon on the Epiphany of the Lord) Secundum Matheum. In epiphania. Omilia (According to Matthew. On the Epiphany. Homily) 
De ammonitione bona (On good advice)

- Purificatio sancta Mari(a)e sermo (Sermon on the Purification of Saint Mary)

- Euuangelium (About the Sow-Man)

- Sermo ad populum (Sermon for the people)

- In capite ieiunij sermo (Sermon on the Beginning of Lent, i.e., Ash Wednesday)

- Dominica palmarum sermo (Sermon on Palm Sunday)

- $\quad$ De die sancto pasce sermo ad populum (Sermon for the people on Holy Easter)

- Sermo necessaria (Indispensable Sermon)

- In ascensione domini nostri Jesu Christi. Sermo ualde necessaria (Very important Sermon on the Ascension of our Lord Jesus Christ)

- In die pentecostén sermo (Sermon on Pentecostal Day)

- In dedicatione tempeli sermo (Sermon on the Consecration of the Temple)

- In dedicatione ecclesie sermo ad populum (Sermon to the people on the Consecration of the Church)

- Admonitio ualde necessaria (Very important advice)

- In inventione sancte crucis sermo (Sermon on the Discovery of the Holy Cross)

- In die sancti Johannis baptiste (On the Day of Saint John the Baptist)

- In die sancti Olavi Regis et martiris (On the Day of Saint Olaf the Martyr)

- Her segir fra Jartæinum hins hælga Olafs konungs (On the Miracles of the King and Saint Olaf)

- Sermo de sancta Maria (Sermon on Saint Mary)

- In exaltatione sancte crucis (On the Glorification of the Holy Cross (14th September)

- Admonitio ualde necessaria. Sanctorum Angelorum. In die sancti Michaelis (Very important advice. The Holy Angel. On the Day of Saint Michael, First Part)

- Inserted leaves: Messuskyringar (Explanations of the Mass). Setningr um prefatior (Sentences about the smallest assistance admitted to Mass). Sermo ad populum ualde necessaria. (Very important Sermon for the people)

- Admonitio ualde necessaria. Sanctorum Angelorum. In die Michaelis (Very important advice. On The Angel Saints. On the Day of Saint Michael, Second Part)

- In die omnium sanctorum sermo (Sermon on the All Saints' Day)

- Sermo de decimis (Sermon on the Tithes)

- Visio Sancto Pauli apostoli ( The Vision of Saint Paul the Apostle)

- Oratio dominica (The Lord's Prayer)

Mariu saga (the Life of the Blessed Virgin) c. 1250 or earlier. There existed many different Mary legends, also in Old Norse, amongst others Transitus Mariae (Unger 1871, Widding \& Bekker-Nielsen 1963).

Placitusdrápa. One of the more popular medieval legends. Old Norse translations are preserved in AM 655, $4^{\circ}$ and AM 644, $4^{\circ}$ as well as in the fragmentary AM 673b, $4^{\circ}$ from around 1200 (Tucker \& Louis-Jensen 1998, Astås 1970).

Soliloquium de arrha animae (translated sometime in the second half of 13th century). The Old Norse text has been preserved in AM 544, $4^{\circ}$, as part of Hauksbók (AM 675, 4º), and in two fragmentary texts: the AM 696 xxxir, $4^{\circ}$ and AM 696 xxxiII, 4. The large composite Hauksbók has survived in two parts, the first containing Landnamabók (about the settling of Iceland) and Kristnissaga (about the Christianisation of Iceland). The second part, in which Soliloquium de arrha animae figures as Vi rae a líkams o $k$ sálar in ff. 60-68 also comprises Trójumanna saga, Breta sögu, Merlinúspá, Fóstbree rasaga, Eríks saga rau a and Voluspá as well as a mathematical treatise called Algoritmus (Har ar son 1995).

Stjórn (c. 1300) contains historical passages of the Old Testament and the Proverbs used mainly as exempla. Stjorn was probably translated sometime in the beginning of the 14th century and have been handed down in the following manuscripts: AM 226 fol. and AM 227 fol. (Astås 1983, 1985a \& 1985b, Kirby 1986, Wolf 1990). Stjórn contains translations from the following books of the Old Testament (heavily interspersed with interlinear commentaries): 
Pentateuch (Genesis, Exodus, Leviticus, Numbers, Deuteronomy), Book of Joshua, Book of Judgment, Book of Ruth, Book of Samuel (I), Book of Samuel (II), The Kings (I), The Kings (II) (until Nebucchodonosor in Chapter 24). C. R. Unger (1862) Stjórn. Gammelnorsk Bibelhistorie fra verden skabelse til det Babylonske fangenskab. Christiania: Feilberg \& Landmarks Forlag.

Vitae Patrum (Heilage manna sögur c.1250-1300), as well as many Latin liturgical songs (Kirby 1986, Tveitane 1968, Firchow 1992).

Elucidarium by Honorius Augustodunensis (Kirby 1986, Tveitane 1968, Firchow 1992).

Visio sancti Pauli. Two distinct Old Norse versions have been preserved - one in the Old Norse Humiliúbók, AM 619, 4 and the other in AM 624, 4. The first version deviates considerable from the Latin standardized text, and in fact resembles more Hugh of Saint Victor's Soliloquium de arrha animae, meaning that it is more a debate between the body and the soul, than a traditional Visio. However, both texts belong to the same medieval visionary tradition (Tveitane 1968, Seip 1952b).

Information extracted from:

Astås 1970, 1983, 1985a \& 1985b, 1990a, Firchow 1992, Halvorsen 1959, Har ar son 1995, Hope 1972, Indrebø 1931, Kirby 1986, Rindal 1980, Seip 1952b, Tucker \& Louis-Jensen 1998, Tveitane 1968, Uecker 1980, Unger 1862, 1864, 1871, 1877, Widding \& Bekker-Nielsen 1963 and Wolf 1995.

\section{SHORT BIBLIOGRAPHY}

"Kristian I’s håndfestning," in Edvard Bull (1977) Nordmenn før oss. Oslo: Tano.

Aarebo, A. (1965): "Hexaëmeron," in Samlede skrifter. Vol. I. Copenhagen: Munksgaards Forlag. ANdersen, P. S. (1977): Samlingen av Norge og kristningen av landet: 800-1130. In series Handbok i Norges Historie: 2.

AstÅs, R. (1985b): “Ordtak i Stjórn I,” in Bibliotheca Arnamagnaena. Vol. XXXVIII. Oslo.

AstÅs, R. (1986): Kompilatoren som kunnskapsformidler i middelalderen in Edda 2. Oslo: Universitetsforlaget. Off-print.

AstÅs, R. (1987a): “Lærd stil, høvisk stil, og florissant stil i norrøn prosa," in Maal og Minne No. 1-2. Oslo: Det Norske Samlaget. Off-print.

AstÅs, R. (1987c): “Om bibelbruk i Kongespeilet," in Arkiv för Nordisk Filologi 102. Oslo. Offprint.

Ast̊̊s, R. (1987d): Et bibelverk fra Middelalderen: Studier i Stjórn. Oslo: Novus.

Augustine (Saint) (1961): Confessions (Trans \& Ed.: R.S. Pine-Coffin). London: Penguin Books. Bagge, S. and K. Mykland (1993): Norge i Dansketiden. Oslo: Cappelen.

BAGGE, S. (1973): Forholdet mellom Kongespeilet og Stjórn. Stensils.

BAGGE, S. (1976): Konge og Kirke i Kongespeilet. Bergen: Universitetsforlaget.

BAGge, S. (1998): Mennesket $i$ middelalderens Norge: Tanke, tro og holdninger 1000-1300. Oslo: Aschehoug.

Barnes, G. (1987): "Arthurian Chivalry in Old Norse," in Arthurian Literature VII. Cambridge: Brewer.

Berdal, O. (1985): Flores og Blancheflor. Introduction by Helge Nordahl. Oslo: Aschehoug \& Akershus Slotts Venner.

Beyer, A. P. (1928): Om Norgis Rige. (Ed.) Harald Beyer. Oslo: Foreningen for Norsk Bokkunst/ Beyers Forlag.

Blaisdell, F. W. and M. Kalinke (Eds.) (1977): Erex saga and Ivents saga: the Old Norse versions of Chrétien de Troyes's Erec and Yvain. Translation and introduction by Blaisdell and Kalinke. Lincoln: University of Nebraska Press.

Brandt, C. J. and R. Th. Fenger (Eds.) (1850): Christiern Pedersens Danske Skrifter. Copenhagen: Gyldendahl.

BrøgGer, A. W. (1947): Konungs Skuggsjá / Norsk Kongespeil. Oslo: Aschehoug. 
Bø, O.(Ed.) (1974): Draumkvedet. Oslo: Dreyer.

Calmette, J. (Ed.) (1925): Mémoires (de Philippe de Commines). 3 Vols. In the series: Les Classiques de l'histoire de France au moyen âge: 3. Paris: Société d'Édition: 5-6.

Carlson, G. (1955): Kalmar Recess 1483. Stockholm: Kungl. Vitterhets Historie och Antikvitets Akademien.

Catholic Encyclopedia (1967-1996): An international work of reference on the teachings, history, organization, and activities of the Catholic Church, and on all institutions, religions, philosophies, and scientific and cultural developments affecting the catholic Church from its beginning to the present. 19 Vols. New York: McGraw-Hill / The Catholic University of America, Washington, DC.

Chavy, P. (1988b): Traducteurs d'autrefois. Moyen Age et Renaissance. Dictionnaire des traducteurs et de la littérature traduite en ancien et moyen français [842-1600]. 2 Vols. Paris: ChampionSlatkine.

Christiansen, R. (1958): The Migratory Legends: A Proposed List of Types (with a Systematic Catalogue of the Norwegian Variants) FCC 175. Helsinki (reprinted in 1977 in New York by Arno Press).

Cook, R. and M. Tveitane (1979): Strengleikar: an Old Norse Translation of Twenty-one Old French Lais. Norrøne Tekster 3. Edited from the manuscript Uppsala De La Gardie 4-7 - AM 666 b, 4º. Oslo: Norsk Historisk Kjeldeinstitutt (XII-XIV, XVI-XVIII).

Danielsen, R., S. Dyrvik, T. Grønli, K. Helle and E. Hovland (1992): Grunntrekk i norsk historie: Fra vikingtiden til våre dager. Oslo: Universitetsforlaget.

Du Bartas, G. de S. (1981): La sepmaine [1581]. Yvonne Bellenger (Ed.). Paris: Nizet.

Ebbestad Hansen, J.-E. (1998) (Ed.): Norsk tro og tanke: 1000-1800. 2 Vols. Anthology of Old Norwegian texts in modern translation. Oslo: Tano Aschehoug.

Ekrem, I. (1992): Halvard Gunnarssøn: Norges Kongekrønike. Oslo: Universitetsforlaget.

Ellingsen, T. (1997): Reformasjonen i Norge. Da kirken valgte kurs. Oslo: Høyskoleforlaget.

ElLINGsen, T. (Ed.) (1988): Kirkeordinansen 1537/39: "Den rette ordinants.” Oslo: Verbum.

Encyclopedia Britannica 2000 (CD-ROM)

FidjestøL, B. (1996): Håvamål. Oslo: Det Norske Samlaget: 60-61.

Firchow, E. S. (1992): The Old Norse Elucidarius. Original Text and English Translation. Columbia/SC: Camden House.

Gløersen, I. (1972): Kongespeilet og Las Siete Partidas. Oslo: Universitetsforlaget.

Gröвer, G. (1908): La Chanson de Roland d'après le manuscrit d'Oxford. Bibliotheca Romanica 53-54. Strasbourg: J. H. E. Heitz.

Grønbech, V. (1913): Religionsskiftet i Norden. Copenhagen.

Halvorsen, E.F. (1959): The Norse version of the Chanson de Roland. Copenhagen: Ejnar Munksgaard.

Halvorsen, E. F. (1972): "Problèmes de la traduction scandinave des textes français du Moyen Age," in Les relations littéraires franco-scandinaves au Moyen Age: Actes du Colloque de Liège (Avril 1972). Paris: Société d’Édition "Les Belles Lettres."

Har AR SON, G. (1995): Littérature et spiritualité en Scandinavie médiévale: la traduction norroise $d u$ De arrha animae de Hugues de Saint-Victor: Étude historique et édition critique. Paris: Brepols.

Helle, K., K. Mykland et al. (Eds.) (1974): “Norge blir en stat: 1130-1319,” in Handbok i Norges Historie 3. Bergen: Universitetsforlaget.

Historia scholastica Magistri Petri Comestoris in Patrologia Latina, Migne, J.-P. Vol. 198. Paris: Migne: 1053-1722.

Holm-Olsen, L. (1998): “Rigstula," in Ebbestad Hansen 1998: 54-60.

Hope, H. (1972): Gamal Norsk Homiliebok. Bergen: Norsk Bokreidingslag.

IndReb $\varnothing$, G. (1931): Gamal norsk homiliebok. Cod. AM $6194^{\circ}$ Oslo: Jacob Dybwad: "De vitutibus et vitiis" (Alcuin) pp. 1-31; "De nativitate domini nostri Iesu Cristi sermo" (Gregory) pp. 3853; "Visio sancti Pauli apostoli," pp. 148-153. Reprinted 1966. 
Jansson, V. (1945): Eufemiavisorna: en filologisk undersökning. Uppsala: A.B. Lundequistska bokhandel.

Johnsen, A. O. (1951): "Les relations intellectuelles entre la France et la Norvège (1150-1214)," in Le Moyen Âge: 57: 247-268.

Jonin, P. (1982): Le Roman de Tristan / Béroul: traduit de l'ancien français par Pierre Jonin. Paris: Champion.

Jónsson, B. (1925): Alexanders saga/ Islandsk oversattelse ved Brandr Jónsson. Copenhagen: Kommissionen for Det Arnamagnaeanske Legat/Gyldendalske Boghandel Nordisk Forlag.

Joubert, C.-H. (Ed.) (1987): Oyez ke dit Marie: étude sur les Lais de Marie de France (XIIe siècle). Paris: José Corti.

Kalinke, M. (1981): King Arthur North-by-Northwest. The matière de Bretagne in Old Norse/ Icelandic Romances. Copenhagen: C.A. Reitzels Bokhandel.

Kalinke, M. (1985a): "Norse Romance," in Old Norse-Icelandic Literature: A Critical Survey. Carol J. Clover \& John Lindow (Eds.). Islandica 45. Ithaca \& London: Cornell UP.

Kalinke, M. (1985b): Bibliography of Old Norse-Icelandic Romances. Ithaca and London: Cornell University Press.

Kalinke, M. (1991): “Translator or Redactor? The problem of Old Norse-Icelandic Translations from Old French Literature," in New Comparison: 12: (Translation in the Middle Ages). Roger Ellis (Ed.). Ithaca NY: Cornell University Press.

KiRby, I. J. (1980): Biblical Quotations in Old Icelandic-Norwegian Religious Literature. Reykjavik: Stofnun Árna Magnússonar á Îslandi 9-10 (Series).

Kleinhans, M. (1993): "Elucidarium" in "Lucidere vault tant a dire comme donnant lumiere": untersuchung und Edition der Prosaversionen 2, 4, und 5 des Elucidarium (Latin and Old French texts in parallel). Tübingen: Niemayer: 260-633.

Kværness, G. (1996): Ein kan godt blote bere det skjer i løyndom. Kristenrettane i Gulatingslova og Grágás og forholdet mellom dei. Oslo: Kult Skriftserie 65.

Le GofF, J. (1985): Les intellectuels au moyen âge. Paris: Seuil.

LiestøL, K. and M. Moe (1912): Norske folkeviser fra middelalderen. Kristiania: Jacob Dybwad.

LiestøL, K. (1915): Norske trollvisor og norrøne sogor. Kristiania: Norli.

Loth, A., K. Togeby and P. Halleux (Eds.) (1980): Karlamagnus Saga: Branches I, III, VII et XI: Édition bilingue. French and Old Norse texts in parallel. Ogier le Danois: 3. Copenhagen: Société pour l'étude de la langue et de la litérature danoise.

Louis-Jensen, J. (Ed.) (1963): Trójumanna saga. Copenhagen: Editiones Arnamagnaeanae, A, 8

Lönnroth, Lars (1972) "Charlemagne, Hrolf Kraki, Olaf Tryggvason: Parallels in the Heroic Tradition," in Maurice Gravier (Ed.) Les Relations littéraires franco-scandinaves au moyen âge (1975). Paris: Société d’Édition "Les Belles Lettres:" 29-52.

Marchello-Nizia, C. (Ed.) (1995): Tristan et Iseut: Les premières versions européennes (amongst others Béroul: Tristan et Iseut; Thomas: Tristan et Iseut, fragment de Carlisle; Marie de France: Le lai du Chèvrefeuille; La folie de Tristam (Berne); La folie de Tristan (Oxford), Eilhart d'Oberg: Tristant; Gottfried de Strasbourg: Tristan et Isolde; Frère Robert: le saga de Tristram et d'Isönd; Sire Tristrem). Paris: Bibliothèque de la Pléiade.

Migne, J.-P. (1844-1864): Patrologiae cursus completus: sive bibliotheca universalis, integra, uniformis, commoda, oeconomica omnium ss. Patrum, doctorum scriptorumque ecclesiasticorum ... Series Latina (Patrologia Latina, PL), 221 Vols. Paris: Migne.

Minnis, A. J. (1988): Medieval Theory of Authorship. 2nd edition. Aldershot: Wildwood House. Moignet, G.(1969): La Chanson de Roland. Paris: Bibliothèque Bordas.

Mortensson-Egnund, I. (1993): Edda Kvede. Oslo: Det Norske Samlaget.

Mortensson-Egnund, I. (1994): Voluspå. Oslo: Det Norske Samlaget.

Mortensson-Egnund, I. (1996): Draumkvedet. Oslo: Det Norske Samlaget.

Mortensson-Egnund, I. (1996): Håvamål. Oslo: Det Norske Samlaget.

Munch, P.A. (1996): Norrøne gude- og heltesagn. Revised edition by Jørgen Haavardsholm. Oslo: Universitetsforlaget. 
Nørlund, P. (Ed.) (1913): Hans Mogensens (1525-1595) Oversattelse af Philippe de Commynes "Memoires" [1574]. Copenhagen: Gyldendalske Boghandel.

Olson, E. (1956): Flores och Blanzeflor. Svenska Fornskrift-Sællskapet. Lund: Carl Blom.

PÁlsson, S. (Ed.) (1944): Heimskringla (Snorri Sturluson). 2 Vols. Reykjavik: Helgafell.

Paton, L. A. (1911): Historia regum Britanniae / The histories of the kings of Britain, by Geoffrey of Monmouth. London: Everyman's Library.

Рум, A. (1998): Method in Translation History. Manchester: St. Jerome Publishing.

Rindal, M. (1980): Barlaams ok Josaphats saga. Manuscript no. 6 fol. in the Royal Library, Stockholm, and the Norwegian fragments. Corpus codicum Norvegicorum medii aevi. Quarto Series: 6. Facsimile Edition. Oslo.

Rindal, M. (1981): Barlaams ok Josaphats saga. Norrøne tekster: 4. Oslo: Kjeldeskriftfondet.

Rychner, J. et P. E. Aebischer (Eds.): Marie de France. Le Lai de Lanval [Texte imprimé]. Texte critique et édition diplomatique des quatre manuscrits français par Jean Rychner. Accompagné du texte du "Januals ljod" et de sa traduction française, avec une introduction et des notes par Paul Aebischer. Geneva: Droz (Paris: Minard).

Rychner, J. (Ed.) (1968): Les Lais de Marie de France. Paris: H. Champion.

Schach, P. (1964): "Tristan and Isolde in Scandinavian Ballad and Folktale," in Scandinavian Studies: 36: 281-297.

SEIP, D. A. (1956): Stjórn: AM 227 fol.: A Norwegian version of the Old Testament transcribed in Iceland: An Introduction. Corpus Codicum Islandorum Medii Aevi 20. Copenhagen: Ejnar Munksgaard.

Snorre, S. (1981): Snorres Kongesagaer (Translated and edited by Anne Holtsmark and Didrik Arup Seip).Gjøvik: Gyldendal.

Sтовм, G. (1899): Laurents Hanssøns sagaoversattelse (Heimskringla). Videnskabselskabet II, Historisk-Filosofisk Klasse 1898:1. Christiania: Hans A. Benneches Fond.

Sørlie, M. (Ed.) (1962): Den Norske Krønike oversatt av M. Størssøn. Bergen: J. D. Beyer / Det Norske språk- og litteraturselskap (Edited from Den norske Krønike om de fraemfaerne Konger, Herrer och Førster, som haffue veldedigenn regiered och styred Norriges Rige/Uddragen af denn gamle norsche paa dansche ved Mattis Størssøn 1594. Manuscript).

Togeby, K. (1972): "La chronologie des versions scandinaves des anciens textes français," in Maurice Gravier (Ed.) Les relations littéraires franco-scandinaves au moyen âge. Paris: Société d'Édition "Les Belles Lettres": 183-192.

Tucker, J. and J. Louis-Jensen (1998) Plácidus saga: with an edition of Plácitus drápa. Editiones Arnamagnána Series B, Vol. 31 Copenhagen: C. A. Reitzel.

Tveitane, M. (1968): Den loerde stil. Oversetterprosa i den norrøne versjonen av Vitae Patrum. Bergen/Oslo: Årbok for Universitetet i Bergen. Humanistisk serie. 1967:2.

Tveitane, M. (1984): "Havets høyhet og luftens letthet: om lærdom og latinismer i norrønt og norsk språk," in Klassisk og norsk. Egil Kraggerud (Ed.). Oslo: Gyldendahl.

Tveitane, M. (Ed.) (1971): Studier over Konungs Skuggsjá. Bergen: Universitetsforlaget.

Uecker, H. (Ed.) (1980): Vienna Psalter: Cod. Viund. 2713. Editiones Arnamagnæanæ. Series B: 27. Latin and Old Norse texts in parallel, commentaries in German. Copenhagen: C.A. Reitzel.

Unger, C. R (Ed.) (1848): Alexanders saga: norsk bearbeidelse fra Trettende Aarhundrede af Philip Gautiers Latinske Digt Alexandreis. (Brandr Jonsson). Christiania: Feilberg \& Landmark.

UNGER, C. R (Ed.) (1853): Saga_ir iks konungs af Bern: Fortollingen om kong Thidrik af Bern og hans Kamper i norsk bearbeidelse fra det trettende Aarhundrede efter Tydske Kilder. Christiania: Feilberg \& Landmark.

Unger, C. R. and P.A. Munch (Eds.) (1847): Fagrskinna: kortfattet norsk Konge-saga fra Slutningen af det tolfte Aarhundrede eller Begyndelsen af det trettende Aarhundrede. Med to lithographerede facsimile-Aftryk. Christiania: Kongelige Norske Fredriks Universitet.

UNGER, C. R. (Ed.) (1862): Stjorn. Gammelnorsk Bibelhistorie fra Verdens Skabelse til det Babyloniske Fangenskap. Christiania: Feilberg \& Landmarks Forlag. 
Unger, C. R. (Ed.) (1864): Gammel Norsk Homiliebok. Christiania: Brøgger \& Christie.

Unger, C. R. (Ed.) (1867): Morkinsskinna: Pergamentsbog fra første Halvdel af det trettende Aarhundrede: Indeholdende en af de celdste Optegnelser af norske Kongesagaer. Christiania: B. M. Bentzen.

Unger, C. R. (Ed.) (1871): Maríu Saga: Legender om Jomfru Maria og hendes Jertegn. Christiania: Brøgger \& Christie.

Unger, C. R. (Ed.) (1874): Postola Sögur: legendariske Fortoellinger om Apostlernes liv, deres Kamp for Kristendommens udbredelse samt deres Martyrdød: efter gamle Haandskrifter. Christiania: B. M. Bentzen.

UNGer, C. R. (Ed.) (1877): Heilagra manna sögur: Fortellinger og Legender om Hellige Moend og Kvinder: efter gamle haards Skrifter (Lives of the Saints). 2 Vols. Christiania: C. R. Unger.

VenÅs, K. (1962): “Innleiing,” to Strengleikar eller Songbok. Henrik Rytter (Ed.). Oslo: Det Norske Samlaget.

Vestergaard Knudsen, H. (1992): “...En fugl der er sluppet ud af buret..?”: Humanisten Christiern Pedersen. University of Copenhagen (Master's Thesis).

Vitae Patrum in Patrologiae cursus completus ... Series Latina, Vols. 73-74. Paris: Migne.

Widding, O. and H. Bekker-Nielsen (1959): "A Debate Of The Body And The Soul In Old Norse Literature," in Mediaeval Studies 21, Toronto: Pontifical Institute of Mediaeval Studies.

Widding, O. (1960) (Ed.): Alkuin i Norsk-Islandsk overlevering (Edit. Arn. A. 4). Copenhagen: E. Munksgaard.

Wolf, K. (1995): Gy ing a saga: Rit Stofnun Árna Magnússonar á Íslandi: 42. Reykjavik: Stofnun Arna Magnussonar.

ZINC, G. (1972): "Les poèmes arthuriens dans les pays scandinaves," in Maurice Gravier (1975) Les relations littéraires franco-scandinaves au moyen âge. Paris: Société d'Édition "Les Belles Lettres."

ØverÅs, A. (1952): Trondheim katedralskole: bygninger og undervisningsrom 1152-1952. Trondheim: F. Bruns Bokhandel. 